\title{
Splenic Marginal Zone Lymphoma in a Patient with Positive Hepatitis B Virus Serology*
}

\author{
Qureshi Iman, Eden Dewi, Bokhari Syed \\ Department of Haematology, University Hospitals Coventry and Warwickshire NHS Trust, Coventry, UK. \\ Email: syed.bokhari@uhcw.nhs.uk
}

Received February $28^{\text {th }}, 2013$; revised March $28^{\text {th }}, 2013$; accepted April $3^{\text {rd }}, 2013$

Copyright (C) 2013 Qureshi Iman et al. This is an open access article distributed under the Creative Commons Attribution License, which permits unrestricted use, distribution, and reproduction in any medium, provided the original work is properly cited. In accordance of the Creative Commons Attribution License all Copyrights (C) 2013 are reserved for SCIRP and the owner of the intellectual property Qureshi Iman et al. All Copyright (C) 2013 are guarded by low and by SCIRP as a guardian.

\begin{abstract}
We present a case in which an elderly woman diagnosed with a splenic marginal zone lymphoma (MZL) was found to have positive Hepatitis B serology. Link with Hepatitis C virus is well documented but reports of association of Hepatitis B virus (HBV) with splenic marginal zone lymphoma are still emerging. A 69-year-old lady presented with weight loss, pancytopenia and marked splenomegaly. Prior to commencing treatment, Hepatitis B serology confirmed Hepatitis B infection. She was treated with Chlorambucil along with anti-hepatitis B prophylaxis and HBV PCR monitoring. She had an excellent response to treatment with resolution of symptoms and splenomegaly. This case highlights the importance of testing for hepatitis B serology in patients diagnosed with splenic MZLs as causative agent. Although the association between $\mathrm{HCV}$ is well documented in the literature, a relationship between HBV may also be important. Also, chemotherapy +/- Rituximab for splenic MZL is associated with the reactivation of latent infections; hence providing prophylactic cover for pre-existing latent HBV infection may be required to prevent reactivation as in this case.
\end{abstract}

Keywords: Splenic Marginal Zone Lymphoma; Hepatitis B

\section{Introduction}

Pathogenesis of Splenic Marginal Zone lymphomas (SMZL) remains unclear with various theories suggesting an antigenic trigger. A link between Hepatitis $\mathrm{C}$ virus (HCV) as a causative factor has been described in the literature. We present a case in which an elderly woman diagnosed with a SMZL was found to have positive Hepatitis B serology, and pose the question of a link between the two conditions.

\section{Case Report}

A 69-year-old female was referred by her general practitioner with a history of epigastric pain and nausea. The patient also complained of weight loss but had no other B-symptoms. She had already had an abdominal ultrasound scan, which showed splenomegaly and enlarged lymph nodes adjacent to the pancreas. Staging CT scan

"The authors declare no conflict of interest. demonstrated a grossly enlarged spleen measuring $22 \mathrm{~cm}$ with multiple hypodense lesions throughout. Lymph nodes were seen at the level of the coeliac axis, gastrohepatic region and porta hepatis. Bone marrow biopsy identified six aggregates of small lymphoid cells. These were monoclonal CD20 positive B lymphocytes. A diagnosis of Splenic Marginal Zone Lymphoma was made.

Initially, a decision was made to observe the patient's clinical course, but within a year she required treatment in view of weight loss, sweats and progressive pancytopenia due to hypersplenism. Rituximab and Chlorambucil chemotherapy was planned and a hepatitis screen was done. Hepatitis B serology confirmed active Hepatitis B infection (HBsAg positive, $\mathrm{HBeAg}$ negative, $\mathrm{HBs}, \mathrm{HBc}$ and $\mathrm{HBe}$ antibodies positive). In view of this, prior to starting any treatment, she was referred to local hepatologist. Hepatitis B DNA by PCR was negative. She was commenced on anti-hepatitis B anti-viral therapy initially with Tenofovir and later, due to intolerance, on Lamivudine $100 \mathrm{mg}$ once daily to prevent any flare-up of the 
Hepatitis B infection.

Once on anti-Hepatitis B treatment, she was treated with monthly cycles of chlorambucil $10 \mathrm{mg}$ for fortnight. During the course of her treatment the patient had regular Hepatitis B quantification by DNA PCR. This was consistently negative, although her HBe antibody remained positive, confirming a carrier state. The patient tolerated 3 cycles of Chlorambucil with partial resolution of splenomegaly down to $15 \mathrm{~cm}$, and a complete resolution of her symptoms and abdominal lymphadenopathy. The patient also was co-incidentally found to have gallstones causing recurrent right hypochonrial pain. As such, she was referred for a splenectomy, which she had in conjunction with a laparoscopic cholecystectomy for coexistent gall stones. The splenic histology confirmed the presence of Marginal Zone Lymphoma. Currently the patient remains in a complete clinical and radiological remission with a follow up of 3.5 years. The patient continues with long term haematological follow up.

\section{Discussion}

MZL represents a group of lymphoid tumors, which originate from memory B-lymphocytes presenting in the marginal zone of the second lymphoid follicles. The World Health Organization (WHO) classifies three distinct types of MZL; Mucosa Associated Lymphoid Tissue lymphoma, Splenic MZL and Nodal MZL [1].

SMZL accounts for $20 \%$ of MZLs and less than $2 \%$ of Non-Hodgkin's lymphoma. The hallmark of clinical presentation of SMZL is massive splenomegaly; however most patients are asymptomatic at diagnosis and may not require treatment for years [2]. The disease commonly pursues an indolent course, with a median overall survival time exceeding ten years. However, the disease can follow an aggressive course in approximately one third of patients and a number of factors have been shown to correlate with survival and prognostic risk stratification models proposed $[3,4]$.

Evidence suggests that all MZL subtypes are associated with an antigenic stimulus and the HCV is closely correlated with SMLZ [5-9]. It has been demonstrated that the E2 glycoprotein of the HCV could interact with CD81 in B cells, thereby leading to a proliferation of B cells [10]. Literature surrounding an association with Hepatitis B virus (HBV) and SMZL is minimal with a few case reports documenting a possible association. Christou et al. [11] presented a middle-aged male diagnosed SMZL on a background of chronic HBV. Lamivudine was commenced prior to chemotherapy and HBV DNA became undetectable. It hypothesized that suppression of lymphocytic p53 function by HBV encoded proteins and chronic antigenic stimulation can promote $a b-$ normal B-cell proliferation, resulting in MZL. Gomez-de et al. [12] discussed the case of fatal hepatitis B reactiva- tion in a splenic MZL patient treated with Rituximab and chemotherapy. Zhang et al. [13] also described a patient with HBV with co-existent hepatocellular carcinoma and SMZL, emphasizing the oncogenic property of this virus. Fujimoto et al. [14] reported a patient who developed a HBV flare up following treatment of SMZL with splenectomy.

Rituximab is a monoclonal antibody that targets the CD20 molecule and the introduction of this antibody has dramatically improved the prognosis of $\mathrm{CD} 20$-positive lymphoma patients. However, it is associated with an increased risk of infectious events as well as the reactivation of HBV in HBsAg-negative patients with malignant lymphoma $[15,16]$. Emerging reports of HBV association with splenic marginal zone lymphoma and Rituxim-abchemotherapy combinations being more effective as compared to chemotherapy alone $[17,18]$ make it even more important to exclude HBV infection prior to commencing treatment.

\section{Conclusion}

This case highlights the importance of testing for hepatitis B serology in patients diagnosed with splenic MZLs as causative agent. Although the association between $\mathrm{HCV}$ is well documented in the literature, a relationship between HBV may also be important. Therefore, testing for such viral serology appears to be an essential part of the management of SMZLs. Also, chemotherapy +/- Rituximab for splenic MZL is associated with the possible reactivation of latent infections; hence providing prophylactic cover for pre-existing latent HBV infection may be required.

\section{REFERENCES}

[1] C. Thieblemont, F. Davi, M. E. Noguera, J. Brière, F. Bertoni, E. Zucca, et al., "Splenic Marginal Zone Lymphoma: Current Knowledge and Future Directions," Oncology (Williston Park), Vol. 26, No. 2, 2012, pp. 194202.

[2] M. Mollejo, F. I. Camacho, P. Algara, E. Ruiz-Ballesteros, J. F. García and M. A. Piris, "Nodal and Splenic Marginal Zone B Cell Lymphomas," Hematological Oncology, Vol. 23, No. 3-4, 2005, pp. 108-118. http://dx.doi.org/10.1002/hon.762

[3] L. Arcaini, M. Lazzarino, N. Colombo, S. Burcheri, E. Boveri, M. Paulli, et al., "Integruppo Italiano Linfomi; Splenic Marginal Zone Lymphoma: A Prognostic Model for Clinical Use," Blood, Vol. 107, No. 12, 2006, pp. 4643-4649. http://dx.doi.org/10.1182/blood-2005-11-4659

[4] C. Montalbán, V. Abraira, L. Arcaini, E. Domingo-Domenech, P. Guisado-Vasco, E. Iannito, et al., "Splenic Marginal Zone Lymphoma Study Group. Risk Stratification for Splenic Marginal Zone Lymphoma Based on Haemoglobin Concentration, Platelet Count, High Lactate 
Dehydrogenase Level and Extrahilar Lymphadenopathy: Development and Validation on 593 Cases," British Journal of Haematology, Vol. 159, No. 2, 2012, pp. 164171. http://dx.doi.org/10.1111/bjh.12011

[5] J. Peveling-Oberhag, G. Crisman, A. Schmidt, C. Döring, M. Lucioni, L. Arcaini, et al., "Dysregulation of Global MicroRNA Expression in Splenic Marginal Zone Lymphoma and Influence of Chronic Hepatitis C Virus Infection," Leukemia, Vol. 26, No. 7, 2012, pp. 1654-1662. http://dx.doi.org/10.1038/leu.2012.29

[6] S. S. Chuang, Y. L. Liao, S. T. Chang, Y. C. Hsieh, S. Y. Kuo, C. L. Lu, et al., "Hepatitis C Virus Infection Is Significantly Associated with Malignant Lymphoma in Taiwan, Particularly with Nodal and Splenic Marginal Zone Lymphomas," Journal of Clinical Pathology, Vol. 63, No. 7, 2010, pp. 595-598.

[7] B. Szynglarewicz, R. Matkowski, Z. Smorag, J. Forgacz, M. Pudelko and J. Kornafel, "Hepatitis C Virus Infection and Locally Advanced Splenic Marginal Zone Lymphoma," Pathology and Oncology Research, Vol. 13, No. 4, 2007, pp. 382-384. http://dx.doi.org/10.1007/BF02940322

[8] G. E. Gurvits, R. Mahtani and I. Halperin, "Hepatitis C Virus and Splenic Marginal Zone Lymphoma with Villous Lymphocytes: Away from Conventional Therapy," Scandinavian Journal of Gastroenterology, Vol. 42, No. 11, 2007, pp. 1392-1393.

http://dx.doi.org/10.1080/00365520701420800

[9] J. Svoboda, C. Andreadis, L. H. Downs, W. T. Miller Jr., D. E. Tsai and S. J. Schuster, "Regression of Advanced Non-Splenic Marginal Zone Lymphoma after Treatment of Hepatitis C Virus Infection," Leuk Lymphoma, Vol. 46, No. 9, 2005, pp. 1365-1368. http://dx.doi.org/10.1080/104281905001028289

[10] L. Arcaini, S. Burcheri, A. Rossi, M. Paulli, R. Bruno, F. Passamonti, et al., "Prevalence of HCV Infection in Nongastric Marginal Zone B-Cell Lymphoma of MALT," Annals of Oncology, Vol. 18, No. 2, 2007, pp. 346-350. http://dx.doi.org/10.1093/annonc/mdl388

[11] L. Christou, G. Kalambokis, M. Bai, S. Kamina and E. V. Tsianos, "Splenic Marginal Zone Lymphoma in a Patient with Chronic Hepatitis B," Journal of Gastrointestinal and Liver Diseases, Vol. 18, No. 4, 2009, pp. 511-512.
[12] E. Gómez-de la Fuente, L. B. Villalón, L. Calzado-Villarreal, F. Pinedo-Moraleda and J. L. López-Estebaranz, "Splenic Marginal Zone B-Cell Lymphoma with Epidermotropic Skin Involvement," Actas Dermosifiliogr, Vol. 103, No. 5, 2012, pp. 427-431. http://dx.doi.org/10.1016/j.ad.2011.06.004

[13] S. H. Zhang, A. M. Xu, J. M. Zheng and M. X. He, "Coexistence of Splenic Marginal Zone Lymphoma with Hepatocellular Carcinoma: A Case Report," Diagnostic Pathology, Vol. 2, 2007, p. 5. http://dx.doi.org/10.1186/1746-1596-2-5

[14] K. Fujimoto, T. Endo, M. Nishio, M. Obara, K. Yamaguchi, Y. Takeda, et al., "Complete Remission of Splenic Marginal Zone Lymphoma after an Acute Flare-Up of Hepatitis B in a Hepatitis B Virus Carrier," International Journal of Hematology, Vol. 90, No. 5, 2009, pp. 601604. http://dx.doi.org/10.1007/s12185-009-0426-y

[15] S. Kusumoto, Y. Tanaka, R. Ueda and M. Mizokami, "Reactivation of Hepatitis B Virus Following RituximabPlus-Steroid Combination Chemotherapy," Journal of Gastroenterology, Vol. 46, No. 1, 2011, pp. 9-16. http://dx.doi.org/10.1007/s00535-010-0331-4

[16] S. Kusumoto, Y. Tanaka, M. Mizokami and R. Ueda, "Clinical Significance of Hepatitis B Virus (HBV)-DNA Monitoring to Detect HBV Reactivation after Systemic Chemotherapy," Journal of Clinical Oncology, Vol. 29, No. 4, 2011, p. e100. http://dx.doi.org/10.1200/JCO.2010.33.0332

[17] C. Kalpadakis, G. A. Pangalis, M. N. Dimopoulou, T. P. Vassilakopoulos, M. C. Kyrtsonis, P. Korkolopoulou, et al., "Rituximab Monotherapy Is Highly Effective in Splenic Marginal Zone Lymphoma," Hematological Oncology, Vol. 25, No. 3, 2007, pp. 127-131. http://dx.doi.org/10.1002/hon.820

[18] E. Zucca, A. Conconi, D. Laszlo, A. López-Guillermo, R. Bouabdallah, B. Coiffier, et al., "Addition of Rituximab to Chlorambucil Produces Superior Event-Free Survival in the Treatment of Patients with Extranodal MarginalZone B-Cell Lymphoma: 5-Year Analysis of the IELSG19 Randomized Study," Journal of Clinical Oncology, Vol. 31, No. 5, 2013, pp. 565-572. http://dx.doi.org/10.1200/JCO.2011.40.6272 